\title{
The Politics of Women's Rights in Iran
}

\author{
Arzoo Osanloo \\ Princeton: Princeton University Press, 2009. 258 pages.
}

Firmly situated in the field of legal anthropology, Arzoo Osanloo's The Politics of Women's Rights in Iran is an ethnographic treatment of women's rights discourse in contemporary Iran. It is concerned with unraveling the assumed paradoxes involved in administering a republican theocracy that attempts to incorporate both divinely inspired legal injunctions and representative forms of governance.

Whereas many conversations concerning human rights and Islam are drowned in contention, normativity, and exegetical speculation, Osanloo's contribution steadily manages to remain above the fray. This is done by placing the discourse of women's rights within the cultural context of globalization and post-colonialism and yet still identifying its local, embodied practice within the shifting political dynamics of post-revolutionary Iran. To this end, through exploring the lives of upper-middle class women in Tehran and their encounters with the emerging Islamo-republican state, the author explores the "conditions [that] have allowed for the discussion of rights to materialize in a language that was unacceptable just after the revolution..." (p. 7), while paying close attention to the ways in which contemporary Iran represents a vernacular modernity expressed through "a hybrid discourse that locates a distinctive form of modernity at the juncture of Islamic revivalism and Western political and legal institutions" (p. 8).

Her theoretical and methodological approach, which incorporates elements of post-colonialism and post-modernism, is presented in a short introudction. Guiding concepts such as "rights as discursive practice," "dialogical sites," and "subjectivization" thus readily inform her mobilization and treatment of the data. Thankfully, her concern for methodological precision does not obscure or consume the narrative form through which she puts forth her thesis in the remainder of the text.

Together, chapters 1 and 2 serve as a primer to the social and political history of Iranian experiments in modern governance over the last century. What the former, "A Genealogy of 'Women's Rights' in Iran," lacks in covering the pre-revolutionary period, it makes up for by elucidating the structural changes in society and government introduced by the events in 1979 and after. Here one is introduced to how the intellectual architects of the Islamic Republic, such as Ayatollah Mutahhari, set forth the theoretical 
foundations for an Islamic conception of gender equity (e.g., not equality) and then how such ideas became more manifest during the Khatami administration (1997-2005). A short insert that outlines the major organs and functions of Iran's complex government structure provides a much needed context without distraction. The latter, "Producing States" establishes the contested locations of the rights discourse in the post-revolutionary political milieu while overviewing the positive systemization of Islamic law into a modern state structure. The theological and jurisprudential debates surrounding this development are illuminated through a review of the political struggles facing Khatami's administration, whose efforts toward greater liberalization were repeatedly obfuscated by entrenched conservatives in various locations of government. For those unfamiliar with Iran's Shi' ite jurisprudential tradition in particular, or with Islamic law more generally, this chapter is inviting yet thorough. In both chapters, Osanloo's ethnographic data couches the material being presented even if it does not move much beyond anecdote.

The following three chapters provide the text's ethnographic core and most thoroughly demonstrate Osanloo's observations regarding complex ways in which the Islamo-republican nature of Iran's state structure allows for unique instances of gender and subject formation in the routine lives of Iranian women. Chapter 3, "Qur'anic Meetings," describes the common Iranian custom of religious and intellectual gathering (jaleseh) - in this case a lay women's Qur'an reading and interpretation group in northwest Tehran. Chapter 4, "Courting Rights," provides unparalleled access into the processes undertaken by women seeking legal redress in Iran's family court via Osanloo's experience as a participant observer in the legal system.

Chapter 5, "Practice and Effect," charts similar phenomena by attending the legal offices of female lawyers known as advocates of women's rights. In these chapters the reader is introduced to women like Nanaz, the leader and convener of a Qur'an reading group who Socratically engages women through an exegesis of Surat al-Baqarah; Sahar, who willingly married at the age of fifteen (now twenty-two) and independently seeks a divorce on the grounds that her husband reneged on his promise to support her goal of completing a college education; or Ms. Tabrizi, a prominent Tehran-based lawyer and daughter of a cleric, who helped draft and advocate a bill that justified post-divorce maintenance (ojrat al-mesl) exclusively upon scriptural grounds. These chapters best demonstrate why Osanloo's deconstruction of false dichotomies such as private/public or personal/social is entirely necessary if one is to understand the social effects and nuance of the bureaucratization of Islamic law in the contemporary world. 
Chapter 6, "Human Rights," a combination of ethnographic anecdote and intellectual history, demonstrates how official Iranian governmental organizations have woven the human rights discourse into the national and religious narratives that make up the rhetorical bases of its existence. Hence, despite the "revolution's anti-imperialist tone and the rejection by Khomeini and his supporters of Western liberal state policies and the language of rights $\ldots$ in the aftermath of the revolution, the language of 'human rights' has reemerged as an important way to give expression to the language of Islamic justice ..." (p. 172). Illuminating how such paradoxes have come into being is the hallmark not only of this chapter, but of the study as a whole.

Returning to the level of geo-politics, this timely conclusion explores how the issue of women's rights in Muslim societies plays into the imperial prerogatives and narratives that seek to maintain a simplified and opposition between "Western Freedom" and "Islamic Opression." Throughout the work, Osanloo offers a "way to think about the status of women in Iran that does not depend on the depiction of 'the rule of radical Islamists,' but instead involves a rethinking of the terms of the debate itself and forces us to move beyond the binaries of East and West, premodern and modern" (p. 205). For this, its much needed accessibility, attention to nuance, and analytic precision, The Politics of Women's Rights in Iran is a valuable contribution to a complex and conflicted field of inquiry.

Abbas Barzegar

Ph.D. Candidate, Graduate Division of Religion

Emory University, Atlanta 